DOI $10.4467 / 2543733$ XSSB.17.028.8326

MARKO BABIĆ

Institute of European Studies

University of Warsaw

\title{
SERBIA'S POLICY TOWARDS KOSOVO AFTER 2000. A TYPOLOGY OF EXPLANATIONS
}

Keywords: Serbia, Kosovo, national identity, ontological security

After the fall of Slobodan Milošević's regime in 2000, Serbia left behind military options in resolving the "Kosovo case". However, an open question remains why Serbia, without any realistic efforts to bring Kosovo back under its sovereignty and despite enormous costs ${ }^{1}$ still insists that "Kosovo is Serbia". For example, European perspectives for Serbia were halted in 2011 due its politics towards Kosovo despite the fact that other technical and political conditions had been fulfilled along with a positive opinion by the European Commission. Then, Serbia failed to gain candidate status.

It is hard to detect strict economic losses related to the phenomenon. Nevertheless, some can be mentioned. For example, on September 9, 2008, the Serbian parliament ratified the Energy Agreement with Russian Gazprom giving the latter a 51\% stake in NIS (Naftna Industrija Srbije), the Serbian oil and gas company that dominates the country's market with a monopoly on refining and a network of almost 500 petrol stations across Serbia. Gazprom bought it for EUR 400 milion $^{2}$ which is far below the realistic value figures estimated between EUR 1 to 2 billion ${ }^{3}$. Apart from this, Serbia's politics on Kosovo cost around EUR 1.9 billion between June 1999 and December 20154. Other, indirect economic losses include delayed economic reforms, the slowing down of regional cooperation and often correct relations with Western powers. If Kosovo, somehow, would have been reintegrated with Serbia, Albanians would have presented $25 \%$ of the population of

${ }^{1}$ www.kolikokostakosovo.info (Accessed: January 10 2017).

2 Serbia in a Tight Spot after Signing Energy Agreement with Russia, "Beta Monitor - Southeast Europe Economic Review", 354, Beograd, September 152008.

${ }^{3}$ Reuters' Oil Report: Serbia Signs Strategic Energy Deal with Russia, 25 January 2008 http://uk.reuters. com/article/uk-russia-serbia-idUKL2515142420080125 (accessed January 20 2017).

${ }^{4}$ http://kolikokostakosovo.info (accessed: January 10, 2017).

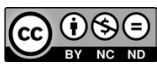


the Serbian state 5 . Due to Albanians' (Kosovars) birth rate (one of the highest in Europe) in the near future, they would be the second largest population in Serbia which would make Serbia a de facto bi-national State. Is this what the Serbian elites were really looking for? Does this insisting on the "Kosovo is Serbia" claim, prove the irrationality of Serbian nationalism or is it rather a rational response of the Serbian elites to the challenges of this new geopolitical situation in the region after 1999?

A very useful tool in understanding this paradox would be Craig Parsons' book "How to Map Arguments in Political Science", where he suggests the typology (logics, as he states) of explanations. He finds four of them: structural, psychological, institutional and ideational ${ }^{6}$. In the book he tries to

make these logics as distinct as possible, such that they designate the separable elemental bits or segments into which all explanations of action can be broken down. (...) In making them analytically separable (...) we could imagine a world in which all were operating while we debate how much variants of each contributed to any given action? ${ }^{7}$.

The aim of the paper, by using Parsons' typology, is to offer some explanations (and understanding) of Serbia's policy towards Kosovo after 2000.

\section{Structural explanation}

Structural arguments, as Parsons explains, state for "what people do as a function of their position vis-à-vis exogenously given 'material' structures" ". Can Serbian politics towards Kosovo be explained by internal or external "exogenously given material structures"? One of the internal structural explanations claims that in deeply divided political communities hard-liners easily control political processes ${ }^{9}$. According to this explanation, small but hard-line political parties and groups veto any potential change in the State's politics towards Kosovo. It would be understandable if only such parties as the Serbian Radical Party or the Serbian Democratic Party (not to mention extremists in "Obraz" or "Srpski Narodni Pokret 1389"10) would have been supporters of such politics. As a matter of fact, in Serbia almost all political parties are supportive of the non-recognition of Kosovo's independence (this also includes the very influential Serbian Orthodox Church).

All the above mentioned actors function within the State, a competent structure that possesses monopoly to use force which is a crucial 'material structure'. When it comes to international affairs the situation changes. According to the founder of neorealism or struc-

5 Serbia's population in 2015 was 7,076.372 (at: http://webrzs.stat.gov.rs/WebSite/Public/PageView. aspx?pKey=2; accessed January 10, 2017) compared to Kosovo's 1,780.000 (at: "Kosovo u brojkama": http:// ask.rks-gov.net/media/2466/kos-ne-shifra-2015-serbe.pdf; accessed January 10, 2017).

${ }^{6}$ C. Pars on s, How to Map Arguments in Political Science, Oxford University Press 2007.

7 Ibidem p. 3.

8 Ibidem p. 12.

${ }^{2}$ H. S pruy t, Ending Empire: Contested Sovereignty and Territorial Partition, Cornell University Press, Ithaca and London 2005.

${ }^{10}$ M. B abić, Defining Political Extremism in the Balkans. The case of Serbia, International Studies, Interdisciplinary Political and Cultural Journal, Vol. 17, No. 1/2015, De Gruyter Open, pp. 86-88. 
tural realism in international relations theory - Kenneth Waltz, "anarchy is seen as one end of a continuum whose other end is marked by the presence of a legitimate and competent government" ${ }^{\prime \prime}$. Another words, the anarchy of the international political systems differ from the order of the national one. In the latter, actors are compelled by a central authority, "the State", "the Government" which further tend to the achievement of their national interests. In the international realm, no such source of order exists. The main goal of the above is to secure survival.

Can Serbian politics towards Kosovo after 2000 be explained by the balance of power in the world or rather by the anarchy of the 'international political systems'? According to the structural realism' explanation, Serbia carried out its diplomatic struggle for keeping the fictional sovereignty over Kosovo due to the anarchic structure of international politics as well as due to a realistic assessment of the international balance of power.

One of the results of anarchic order in international relations is, according to Waltz, that units of the international order are sovereign - they take care of themselves. Contrary to the national system, the international system is a system of "self-help": "To achieve their objectives and maintain their security units in a condition of anarchy (...) must rely on the means they can generate and the arrangements they can make for themselves. Self-help is necessarily the principle of action in an anarchic order"12. For a State to be sovereign means that it is independent in resolving internal and external problems and whether it would ask others for help, ipso facto, limiting its freedom. Another structural realist, John Mirsheimer, claims that a smaller territory means a smaller population and less resources which results in weaker chances of survival. According to him, survival is the principal motive behind a State's behaviour ${ }^{13}$. According to this logic, no State would accept the unilateral secession of a part of its territory because that would result in losing its own autonomy.

Has this also been the logic of Serbian politics? Political elites refused to accept that Kosovo was a sui generis case and therefore were against it and unilaterally declared independence in 2008. However, it seems that the elites estimated that using force to protect Serbia's sovereignty was pointless as this would mean another war with NATO with all the consequences. Serbia wanted to protect its national interests by trying to avoid a war. Accordingly, with Russia's support Serbia aimed to change the unfavourable balance of power within the Contact Group (USA, Great Britain, Germany, France, Italy and Russian Federation) as a majority of the group was supportive of Kosovo's independence.

This structural explanation is not as clear as it appears. For example, would the strategic political and military shift towards the alliance with Russia had not been made if the protection of sovereignty in Kosovo belonged to Serbian vital national interests? Instead, the Russian veto in the UN Security Council seemed to be sufficient in keeping this fictional sovereignty. At the same time, since 2000 Serbia got closer to the states which directly question Serbia's sovereignty over Kosovo in economic and military terms. After Milošević's fall in October 2000 Serbia's strategic goal has been accession to the European Union as well as "flirting" with NATO membership (which is contrary to what Russia would approve).

11 K. Walt z, Theory of International Politics, Addison-Wesley Publishing, 1979 p. 114.

12 Ibidem p. 111.

13 J. Mirs cheimer, Anarchy and the Struggle for power, [In:] The Tragedy of Great Power Politics, New York and London, W. W. Norton Company 2001 p. 54. 
Structural realists such as Mirscheimer claim that "states seek to maintain their territorial integrity and the autonomy of their domestic order"14. If this is so, then why did Serbia resign from using power as an instrument of protecting its "national interests"? To the contrary, Serbian officials many times claimed that Serbia resigned from using power in resolving the "Kosovo question" in favour of diplomatic means. This shows that structural realism can be an explanation tool of Serbian politics about Kosovo just to a certain extent. It cannot however explain its means and strategies.

But, the founder of structural realism, Kenneth Waltz, never claimed that states would always act according to material structure of international politics. His point is that the states that do not do that would be in trouble ${ }^{15}$. So, even if a structural realist correctly noticed that the structure decides on State behaviour, an open question remains why Serbia did not act in accordance to the principles of anarchic structure of the international order and in accordance with the actual power distribution in the international system.

History knows various scenarios on how states treat their territories. Some of them were prepared to go on war to defend their territories regardless how small they were (for example, Great Britain - Argentina war over Falklands in 1982). Examples of peaceful secession are also known: Norway from Sweden in 1905 or Island from Denmark in 1918. However, secessions are usually followed by violence as states do not voluntarily approve their provinces to secede. There are examples though that despite lost wars states were prepared to recognize the new reality and give secessionist independence: Great Britain recognized their independence only two years after the lost war against American colonists (1783). The case of France and Algeria is particularly interesting. The latter was a French colony from 1848 to 1962 . The similarities are as follows that despite the fact that Kosovo was never a Serbian colony (as Algeria used to be a French colony), however both territories were gained by war and a majority of the population was opposed to the State administration (ruled from the centre). However, France recognized Algeria on July 3, 1963 after eight years of war (1954-1962) and only two days after the independence referendum ${ }^{16}$. These examples show us that it is not unusual to recognize secession if it is a claim of a majority of the population of the disputed territory and after an armed conflict was won by secession. The State's attachment to the territory is not only an objective category that can be derived from the anarchic nature of the international order (or from the "third image" of international relations ${ }^{17}$ ) as structural realists claim. It is also a subjective category derived from various psychological factors (or the "first image" of international relations $)^{18}$. It is a result of the way a State (a political community) understands itself.

Therefore it is necessary to take a closer look at the potential psychological and ideological explanations of Serbian politics towards Kosovo.

$14 \mathrm{http}: / /$ mearsheimer.uchicago.edu/pdfs/StructuralRealism.pdf, p. 74 (accessed January 12, 2017).

$15 \mathrm{~K}$. Walt z, Theory of International Politics.

16 M. Evan s, Algeria, France's Undeclared War, Oxford University Press 2012.

17 Trying to answer the question: Where are the major causes of war to be found? Waltz explains that "the answers are bewildering in their variety and in their contradictory qualities. To make it manageable the answers can be ordered under the following three headings: 1 . within man, 2 . within the structure of the separate state, 3. within the state system". He refers to them as images of international relations. See: K. Wa l t z, Man, the State and War, A Theoretical Analysis, Columbia University Press, New York 2001, p. 12.

18 Ibidem. 


\section{Psychological explanations}

According to Parsons, psychological explanations “(...) focus on irrationality. The core of psychological logic consist of claim that people arrive at certain actions because they analyze, categorize, perceive, judge, desire, feel, or instinctively need in irrational ways"19. In Waltz's understanding psychological explanations belong to the "first image" (within man). The starting point for this explanation lies in the aims and abilities of the individual decision makers deciding on State strategies.

There were few psychological explanations in Serbia's politics towards Kosovo after the fall of Slobodan Milošević on October 5, 2000. The first one suggests that it was the result of "group thinking" within political parties. Decision makers are aware that any changes in regards to already designated views on the "Kosovo case" would have weakened not only their position within the party, but the position of their party vis-à-vis other political parties. As rational actors, they refuse to consider any radical alternatives to Serbia's official politics on Kosovo. The second one is a "prisoners' dilemma" understood as a way that both parties choose to protect themselves at the expense of the other participant. As a result of the following logical thought process, both participants find themselves in a worse state than had they cooperated with each other in the decision-making process. In other words, political leaders defend the positions of their parties by keeping away from the "Kosovo case". Although for them it is morally and politically biding, in reality it is unattainable and therefore for Serbia is "a worse state". The third one shows distrust among parties and understanding of the politics as "zero-sum game".

All of the above explanations are without doubts a part of the truth. It seems obvious that all of them are rather consequences than the cause of these politics. But, an open question remains why these politics have been taboo to this extent? The ideological construction of the idea that Kosovo is a part of Serbia caused politicians to rationally comply with this construction in fear that opening a critical debate over the issue would open a debate about themselves. Can we search for a psychological explanation of Serbia's "Kosovo politics" in individual-psychological profiles of political leaders in Serbia? The differences between, for example, Slobodan Milošević, Vojislav Koštunica or Boris Tadić when it comes to personality, character or way of governing are more than obvious. But how can it be explained that all the representatives of Serbian politics almost ritually objected Kosovo's independence? The fact remains that Serbian politics towards Kosovo have been an obsession for generations of Serbian politicians.

Another psychological explanation can refer to the Chip Gagnon notion that political elites in Serbia manipulated this ethnic conflict as a way to short-circuit the dynamics of political changes and divert attention from other significant problems in the Serbian society $^{20}$. Even if it this so, it remains unclear what interest he is referring to, to as these politics have been a continuous failure that resulted in questioning also other priorities of the Serbian internal and foreign policy. Milošević came to power in the late 1980s and had to resign from power in 2000 due to politics towards Kosovo, Koštunica resigned

19 C. P ars on s, How to Map Arguments..., p. 138.

${ }^{20}$ V. P. Gagnon, The Myth of Ethnic War: Serbia and Croatia in the 1990s, Cornell University Press, Ithaca 2004. 
from the Office due to the inability to prevent the declaration of Kosovo's independence, Tadić's greatest political failure was about Kosovo. It remains to be seen how Aleksandar Vučić will deal with the same problem. Nevertheless, it would be hard to determine any rational personal or party political interests in Serbia's politics towards Kosovo thus far.

Another approach suggests that there is a strategic plan to prolong the recognition of the independence of Kosovo for as long as possible. The goal would eventually be to "exchange" Kosovo for other benefits (a faster accession process to the European Union, the division of Kosovo, or even the exchange the Preševo Valey for the northern part of Kosovo inhabited by the Serbs etc.). The Brussels Agreement signed on April 19, 2013 between Serbia and Kosovo denied, to a certain extent, the above suggestions: the agreement opened the way to membership in the European Union for both countries (in the case of Serbia, it helped membership negotiations to commence on January 21, 2014). This 15-point agreement provided the merger of the four Serb municipalities in the north: North Mitrovica, Zvečan, Zubin Potok and Leposavić subject to Kosovo law. The agreement also stipulated that only Kosovo police force would be deployed in the north, but the regional commander would be a Serb. The crucial point was that both parties had agreed not to hinder the other's efforts to gain European Union membership.

Nevertheless, there is uncertainty regarding the implementation of the agreement. Even if Serbia's ultimate goal would be the division of Kosovo, "first you need to recognize Kosovo in order to divide it", claims Serbian political analyst Dušan Janjić2 ${ }^{21}$. Serbian politics towards Kosovo might continue on the tracks of the Brussels Agreement in 2013, but might also go in another direction.

As we can see, applied psychological arguments do not provide satisfactory explanations for Serbia's Kosovo politics after 2000. It is necessary to use the last group of arguments - ideational explanations.

\section{Ideational explanations}

Craig Parsons explains that "ideational claims explain what people do as a function of the cognitive and/or affective elements that organize their thinking, and see these elements as created by certain historical groups of people"22. These explanations should provide us with answers why Serbia is so emotionally and symbolically linked to the Kosovo territory. What is the ideological relationship between knowledge and power that keeps this link current? Finally, why does this matter continue to be taboo even for political parties and political leaders opting for a radical discontinuity with previous Serbian politics towards Kosovo ${ }^{23}$.

Understanding a relationship between territory and national identity seems to be of significant importance, particularly in the case of a nation-state which in "corporate identity is drawn from its territoriality" as Alexander Wendt ${ }^{24}$ once stated. Emotional ties

${ }^{21}$ Podela Kosovo samo u interesu Srbije, Danas, July 13 2010. http://www.danas.rs/danasrs/politika/podela_kosova_samo_u_interesu_srbije.56.html?news_id=194898 (accessed: January 23, 2107).

22 C. P arson s, How to Map Arguments..., p. 12.

${ }^{23}$ Čedomir Jovanović, a liberal politician, is a good example of this attitude.

24 A. We n d t, Social Theory of International Politics, Cambridge University Press, Cambridge 1999, p. 225. 
may vary depending on historic, cultural, political or strategic significance the territory presents for the nation. According to George White, the very core of a national identity is intimately bound to specific places where nations define themselves in terms of spaces that have historical, linguistic and religious meaning ${ }^{25}$. He sees Serbia's attitude towards Kosovo as a clear demonstration of the above.

Kosovo has been designed as a territory of central importance for Serbia. Therefore, efforts to maintain fictitious sovereignty over it are explainable through a strong ideological structure that defines the boundaries of what can be said and done in the framework of political legitimacy. The fact that the ideational explanation in this paper is constructivist and should be distinguished from ideational explanations offered by Serbian nationalists which, in its essence, is essentialist, must, however, be taken into consideration. Nationalist politicians and intellectuals claim that Kosovo is the "cradle" of the Serbian state and nation, and as such is embedded in the "core of national identity". The essentialist view is politically powerful but analytically weak. Is Kosovo a "cradle" of Serbia and Serbdom? Historically, Kosovo had been a part of Serbia for only 243 years: in Middle Ages from 1216 to 1459 and in the XX century 1912-1915, 1918-1941 and 1945-1999. Another essentialist argument that no state has ever resigned from a part of its territory seems to be untrue. For example, Prussia as a German core country was situated mostly what is not todays' German territory (former Prussia's territories now belong to Poland, Lithuania and Russian Federation). Germany resigned from territorial aspirations towards this land. A "cradle" of the modern Russian state was the Kievan Rus known as the "land of the Rus". This loose federation existed from the late 9th century to the mid-13th century. It stretched from the Baltic Sea in the north to the Black Sea in the south uniting the majority of East Slavic tribes. The capitol was Kiev which is in today's Ukraine.

The constructivist explanation shares an assumption with essentialists that Kosovo represents the "Ethnoscape ${ }^{26}$ for Serbia - the sacred ethnohistorical territory associated with the myth of origin of the community. But unlike essentialists who think that this is an objective historical well-known fact about the trans-historical and trans-contextual truth about the Serbian national identity, constructivists start from the historical and contextual contingency and invented importance of the territory of Kosovo. The constructivist-ideational explanation aims to give an answer to the question who and when gave Kosovo the status of a sacred land without which Serbdom and the Serbian State would be endangered. Undoubtedly, this point of view is a result of social and political structures. The Serbian Kosovo policy after 2000 and the fall of Slobodan Milošević can be understood as a form of rational behaviour in order to preserve the ontological security which is the ability to maintain the continuity and biographical narrative about itself.

Sometimes the state undertakes social activities that serve the needs of its self-identity, even when these activities threaten the state's physical existence. Maintaining biographical continuity allows "small nations" who constantly fear for existence to gain existential security. This undoubtedly concerns the Serbs. There is an overwhelming concern in the Serbian public narrative that, throughout history, the territory of Serbia and other neighbouring re-

${ }^{25}$ G. W hite, Nationalism and Territory: Constructing Group Identity in South-East Europe, Rowman and Littlefield, Oxford 2000.

${ }^{26}$ A. S mith, Sacred Territories and National Conflict, Israel Affairs, Vol. 5, No. 4, 1999, pp. 13-29. 
gions where Serbs live is being permanently reduced. Due to the frequent wars and negative demographic tendencies (including the unfavourable age structure), the Serbian population has decreased ${ }^{27}$. This can be called Serbian demographic and territorial pessimism. Political elites have no explicit vision to change this narrative. By repeating the slogan "Kosovo is Serbia" they exclude all other narratives and challenges that may threaten Serbian society and state from the political agenda (unemployment, "brain-drain" process and many others).

This policy towards Kosovo might seem irrational regarding the material interests of Serbia. But understood as a need to preserve the ontological security or biographical continuity of the nation, this policy is rational and reasonable ${ }^{28}$. In other words, the policy may be understood as a vision of a rational policy that allows keeping the narrative as well as the self-image that the state and the nation have about themselves. Without such narratives their identity might be endangered and conceptually might fall apart. If there is a sudden interruption of such narratives, the state and the nation would be disgraced and eventually fall into a state of ontological insecurity. Fearing disgrace, they seek to preserve a self-image that provides them a sense of ontological security. Its preservation therefore remains a rational policy. The continuous denial of reality in Kosovo aims to (re)product as well as reconstruct narratives concerning the state and the national identity. On the one hand, this activity faces the international community through requirements for recognition of the identity of Serbia as a sovereign state and the Serbian Nation as a nation with medieval roots. At the same time, this policy domestically does not serve as a "transfer of information" but as an internal dialogue that shapes the self-identity of the Serbian state and the Serbian nation. In both cases, it does not only concern the reproduction of old narrative but also their reconstruction and adaptation. Thus, Serbia through the Kosovo policy confirms its identity as an old and a sovereign state as well as an identity as a peaceful and democratic European country.

The foreign and security policy of Serbia towards Kosovo is not objectively derived from national identity or history. It is not neither a defence mechanism of some independent "imaginary we" as supporters of societal security concept would suggest ${ }^{29}$. Through the "Kosovo is Serbia" discourse and its political implementation, Serbian political elites not only defend but reproduce the "imaginary we," thus maintaining the ontological security of the collective, which indirectly stabilizes ontological security of individuals.

${ }^{27}$ Goran Panev explains that changes in the age structure of the Serbian population were primarily influenced by the decline in fertility. The long term effects of the inherited age structure of its future changes are more than obvious. Disruptions in the age structure caused by the First and the Second World War, the rapid increase in fertility during the early 1950s, and later relatively intense fertility decrease, were the main direct factors that shaped the age structure of the population of Serbia during the second half of the 20th century. Over time, with increasingly intense biological departure of depleted generations that suffered the most in the world wars, the effect of previous disturbances of age structure became less pronounced. later, in the late 20th century, the impact of long-term effect of low fertility became increasingly pronounced and in the last twenty years also the impact of turbulent migration. See: G. P a n e v, Population ageing trends in Serbia from the beginning of the 21st century and Prospects until 2061: Regional Aspect, Зборник Матице Српске за друштвене науке, No. 148 (Vol. 3/2014), Београд 2014, p. 688.

${ }^{28}$ It does not mean however that it is the only rational, possible and conceivable policy.

${ }^{29}$ O. Wa e ver, The Changing Agenda of Societal Security, [in:] Brauch, Hans Gunter et a., (eds.), Globalization and Environmental Challenges, Reconceptualization Security in the 21st Century, Springer, BerlinHeidelberg 2008, pp. 581-593. 
The process of social construction of the ontological security (and insecurity) represents Michel Foucault's "technologies of the self" which "permit individuals to effect by their own means or with the help of others a certain number of operations on their own bodies and souls, thoughts, conduct and way of being, so as to transform themselves on order to attain a certain state of happiness, purity, wisdom, perfection or immortality"30.

This technology of power is fixed on rituals and imposes rights and obligations. Anyone who dares to question this quickly becomes delegitimized as a traitor, and then excluded from the political community. In other words, the political elites not only secure political legitimacy within the political community for themselves but reconstitute the very political community by (re)drawing out its boundaries. Therefore, the withdrawal from Kosovo is seen as a prelude to social anomie understood as a suspension or inefficiency of social norms, laws, regulations and values ${ }^{31}$. This situation would bring a time of social and political crisis when earlier norms and traditional values could not be applied anymore. It would lead to confusion and disorientation in the society and might bring potential state disintegration.

\section{Conclusions}

One can be wonderstruck about how to explain continuity in Serbian aspirations towards Kosovo after the country lost chances to control and manage this territory. Why has democratic Serbia stubbornly opposed Kosovo's independence after the fall of Slobodan Milošević in 2000 avoiding to offer a realistic alternative in spite of the enormous political, economic cost and the loss of reputation? The paper indicated institutional, structural, psychological and ideational explanations of the Serbian Kosovo policy. One may conclude that all of them demonstrated interpretative limitations in understanding this phenomenon. Nevertheless, such a policy can be seen as a rational effort to preserve the ontological security of the State. Precisely, Serbia experienced the declaration of independence of its southern province as a fundamental challenge for its identity that must be faced with all available peaceful and diplomatic means.

It seems that a resolution of this stalemate of ontological dissonance might be in a "transformation of the Self". This new policy discourse on national identity would have to be changed and adapted by replacing the Kosovo metanarrative with other metanarrative(s) which would offer Serbian society a new legitimation through the anticipated completion of a new master idea ${ }^{32}$. One thing is certain: the security policy of Serbia towards Kosovo cannot be fully understood nor changed without attempting to change the concept of collective identity.

${ }^{30}$ Foucault claims to be four major types of "technologies: 1) technologies of production which permit us to produce, transform or manipulate things; 2) technologies of sign systems, which permits us to use signs, meaning, symbols or signification; 3) technologies of power which determine the conduct of individuals and submit them to certain ends or domination, an objectivizing of the subject. The fourth one is cited above. See: M. F o u c a u 1t, Technologies of the Self, [in:] Technologies of the Self: A Seminar with Michel Foucault, L. Martin, H. Gutman, P. Hutton (eds.), University of Massachusets Press, 1988, p. 16-49.

${ }^{31}$ More on social anomie see: E. Durkheim, The Division of Labor in Society, The Free Press, New York 1993 and from the same author: Suicide. A Study in Sociology, The Free Press, New York 1979.

32 J.-P. Ly o ta rd, Postmodernizm dla dzieci, Altheia, Warszawa 1998, pp. 30-31. 


\section{Bibliography}

Babić Marko, Defining Political Extremism in the Balkans. The case of Serbia, International Studies, Interdisciplinary Political and Cultural Journal, Vol.17, No.1/2015, De Gruyter Open

Durkheim Emil, The Division of Labor in Society, The Free Press, New York 1993

Evans Martin, Algeria, France's Undeclared War, Oxford University Press 2012

Foucault Michel, Technologies of the Self, edited by Martin H. Luther, Huck Gutman and Patrick Hutton, University of Massachusets Press, 1988

Gagnon V.P., The Myth of Ethnic War: Serbia and Croatia in the 1990s, Cornell University Press, Ithaca 2004

Lyotard Jean-Francois, Postmodernizm dla dzieci, Altheia Warszawa 1998

Mirscheimer John, Anarchy and the Struggle for power, [in:] The Tragedy of Great Power Politics, New York and London, W.W. Norton Company 2001

Panev Goran, Population ageing trends in Serbia from the beginning of the 21st century and Prospects until 2061: Regional Aspect, Зборник Матице Српске за друштвене науке, No. 148 (Vol. 3/2014), Београд 2014

Parsons Craig, How to Map Arguments in Political Science, Oxford University Press 2007

Smith Anthony, Sacred Territories and National Conflict, Israel Affairs, Vol. 5, No. 4, 1999

Spruyt Hendrik, Ending Empire: Contested Sovereignty and Territorial Partition, Cornell University Press, Ithaca and London 2005

Waever Ole, The Changing Agenda of Societal Security, [in:] Brauch, Hans Gunter et al., (eds.), Globalization and Envirnomental Challenges, Reconceptualization Security in the 21st Centu$r y$, Springer, Berlin-Heidelberg 2008

Waltz Kenneth, Theory of International Politics, Addison-Wesley Publishing, 1979

Waltz Kenneth, Man, the State and War, A Theoretical Analysis, Columbia University Press, New York 2001

Wendt Alexander, Social Theory of International Politics, Cambridge University Press, Cambridge 1999

White George, Nationalism and Territory: Constructing Group Identity in South-East Europe, Rowman and Littlefield, Oxford 2000

\section{Marko Babić}

\section{Serbia's Policy towards Kosovo after 2000. A Typology of Explanations}

\section{Summary}

Serbia's stubborness to recognize Kosovo independence and a continuous effort to bring Kosovo back under its state jurisdiction seems to be in political terms irrational. However, this has been a continuous strategy of all Serbian governments since Milosevićs' fall in 2000. The aim of the paper is to try to give explanations to this, at first sight, paradoxical phenomenon. Is there any rationality in this irrationality? Author finds Craig Parsons's typology of explanations very useful in understanding the phenomenon of Serbia's politics toward Kosovo after 2000.

Keywords: Serbia, Kosovo, national identity, ontological security. 